\title{
Cơ hội và thách thức cho Lâm nghiệp đô thị
}

\author{
Phạm Thu Thủy, Nguyễn Thị Thủy Anh, Nguyễn Thị Vân Anh và Trần Ngọc Mỹ Hoa
}

\section{Thông điệp chính}

- Lâm nghiệp đô thị có vai trò quan trọng trong việc thích ứng và giảm thiểu biến đổi khí hậu

- Mặc dù có nhiều khái niệm khác nhau về rừng và lâm nghiệp đô thị đang được áp dụng trên thế giới, các khái niệm này đều nhấn mạnh về vai trò của hệ sinh thái cây xanh, thảm thực vật trong nội thành và các vùng lân cận trong việc đảm bảo lợi ích xã hội, kinh tế, môi trường và an sinh cho cư dân đô thị

- Xây dựng chính sách lâm nghiệp đô thị cần sự phát triển đông đều về chính sách trên 3 lính vực: xác định định nghĩa và phạm vi hoạt động rõ ràng về rừng và lâm nghiệp đô thị trong các văn kiện chính sách; xây dựng các chính sách quản lý rừng và lâm nghiệp đô thị (quy hoạch, hướng dẫn kĩ thuật, quy trình quản lý, xây dựng đội ngũ nhân lực, giám sát và đánh giá); xây dựng chính sách huy động nguồn lực và sự tham gia của các bên có liên quan vào thực hiện chính sách lâm nghiệp đô thị

- Có nhiều cơ hội để lâm nghiệp đô thị phát triển và đi vào thực tế đặc biệt khi biến đổi khí hậu và ô nhiễm môi trường đã khiến nhu cầu về cây xanh và không khí trong lành trở thành ưu tiên của các cư dân đô thị và ven đô. Ngoài ra, sự tồn tại của Vườn bách thảo - nơi lưu giữ các kinh nghiệm lâu năm và liên tục trong việc thực hiện các giải pháp cây trồng phù hợp với điều kiện đô thị đã tạo ra một nền tảng kiến thức lí thuyết và thực tiễn sẵn có. Tuy nhiên, triển khai lâm nghiệp đô thị cũng gặp nhiều thách thức, đặc biệt là khi sự thành công của chính sách này phụ thuộc rất nhiều việc hiệu quả của sự phối hợp giữa các cấp và các ngành quản lý.

\section{Mở đầu}

Lâm nghiệp đô thị hiện đang được coi là xu thế phát triển trong tương lai của ngành lâm nghiệp trên toàn cầu, đặc biệt trong bối cảnh biến đổi khí hậu. Được phát triển mạnh mẽ tại Mỹ vào những năm 1970s, sau đó được du nhập và phát triển tại Châu Âu vào những năm 1990s, lâm nghiệp nghiệp đô thị đã dần phát triển trên toàn cầu và ngày càng nhiều quốc Châu Á quan tâm tới chính sách này. Tại Việt Nam, khái niệm lâm nghiệp đô thị vẫn còn mới mẻ và các kiến thức nền tảng liên quan đến chính sách lâm nghiệp đô thị chưa được các bên có liên quan biết đến. Trong quá trình xây dựng Chiến lược phát triển lâm nghiệp giai đoạn 2021- 2030, tầm nhìn 2050, Bộ Nông Nghiệp và Phát Triển Nông Thôn đã xem xét tới khả năng đưa lâm nghiệp đô thị vào văn kiện chính sách quan trọng này. Tuy nhiên, còn có rất ít các nghiên cứu cơ bản liên quan đến lĩnh vực này, do vậy cơ sở khoa học và cơ sở pháp lý đưa chính sách này vào thực tiễn còn gặp nhiều khó khăn. Nhằm cung cấp thông tin đầu vào cho quá trình xây dựng Chiến lược phát triển lâm nghiệp Việt Nam giai đoạn 2021- 2030, tầm nhìn 2050, tài liệu tóm lược chính sách này cung cấp một số thông tin cơ bản về khái niệm, phạm vi, chính sách cũng như cơ hội và thách thức đối với lâm nghiệp đô thị trên thế giới nói chung và tại Việt Nam nói riêng. Tóm lược chính sách này dựa trên việc rà soát các tài liệu thứ cấp.

\section{Khái niệm}

Hiện nay có nhiều định nghĩa về lâm nghiệp đô thị đang được áp dụng trên thế giới (Bảng 1). Tuy nhiên, phần lớn các định nghĩa này đều nhấn mạnh tới vai trò 
tầm quan trọng của hệ sinh thái và thảm thực vật có cây rừng trong việc đảm bảo các lợi ích kinh tế, xã hội, môi trường của dân cư đô thị.

Các định nghĩa nói trên chỉ ra phạm vi hoạt động của lâm nghiệp đô thị cũng rất rộng và có thể tóm tắt trong Hình 1 dưới đây.

\section{Các quy định pháp luật của lâm nghiệp đồ thị}

Khi xây dựng hệ thống chính sách lâm nghiệp độ thị, các quốc gia thường tập trung vào 3 mảng chính sách (Hình 2)

\section{Xây dựng định nghĩa rõ ràng về rừng đô thị và lâm nghiệp đô thị trong các văn bản quy phạm pháp luật \\ Một trong nhứng khó khăn các quốc gia gặp phải đó là định nghĩa chung về rừng không thể áp dụng được trong bối cảnh đô thị. Các yêu câu tối thiểu về diện}

tích, độ che phủ, hệ sinh thái được sử dụng để định nghĩa rừng thông thường sẽ không thể đạt được tại các vùng đô thị. Để giải quyết vấn đề này, cần có định nghĩa cụ thể về nội dung và phạm vi hoạt động của rừng và lâm nghiệp đô thị trong hệ thống văn bản pháp luật. Tuy mỗi quốc gia và tổ chức có cách định nghĩa khác nhau tùy vào mục tiêu quản lý của mình, Bảng 1 cho thấy định nghĩa về rừng và lâm nghiệp đô thị không chỉ được gói gọn trong các định nghĩa về rừng thông thường, vốn thuần túy thể hiện các điều kiện sinh thái tự nhiên mà tập trung vào vai trò và vị trí của hệ sinh thái tự nhiên trong việc đảm bảo lợi ích môi trường, kinh tế, xã hội và an sinh của cư dân đô thị. Bảng 1 cũng cung cấp các ví du về cách tiếp cận về rừng và lâm nghiệp đô thị mà Việt Nam có thể xem xét và lồng ghép trong các chính sách về lâm nghiệp hiện hành.

\section{Xây dựng chính sách quản lý rừng và lâm nghiệp đô thị}

Xây dựng chính sách quản lý rừng và lâm nghiệp đô thị bao gồm nhiều hoạt động và quy định (Bảng 2).

Bảng 1. Một số định nghĩa lâm nghiệp đô thị hiện hành

\begin{tabular}{|c|c|}
\hline Định nghĩa lâm nghiệp đô thị & Nguồn \\
\hline $\begin{array}{l}\text { Rừng trong đô thị là một hệ sinh thái bao gồm các loài cây, thực vật và các loài động vật liên } \\
\text { quan trong môi trường đô thị trong và xung quanh thành phố. }\end{array}$ & Jess 2020 \\
\hline $\begin{array}{l}\text { Lâm nghiệp đô thị bao gồm diện tích đất có cây và các tài nguyên có liên quan trong hoặc xung } \\
\text { xanh khu vực có tác động của con người, bao gồm từ các cộng đồng nhỏ tới các trung tâm đô thị } \\
\text { lớn đông người }\end{array}$ & Lidija 2005 \\
\hline $\begin{array}{l}\text { Lâm nghiệp đô thị là nghệ thuật, khoa học, công nghệ để quản lý cây xanh và tài nguyên rừng } \\
\text { trong và xung quanh cộng đông đô thị và hệ sinh thái vì mục đích kinh tế, xã hội, an sinh } \\
\text { của xã hội }\end{array}$ & Helms 1998 \\
\hline $\begin{array}{l}\text { Lâm nghiệp đô thị là một phương pháp tiếp cận tổng hợp, trong đó việc trồng, bảo vệ, chăm sóc } \\
\text { và quản lý cây xanh trong đô thị được tiến hành nhằm đảm bảo các lợi ích môi trường, kinh tế, xã } \\
\text { hội cho cư dân đô thị }\end{array}$ & FAO 2010 \\
\hline $\begin{array}{l}\text { Rừng đô thị bao gồm tất cả các cây xanh và thảm thực vật trong và xung quanh khu vực con } \\
\text { người sinh sống. Diện tích thực vật này không bao gồm khu vực canh tác nông nghiệp và cung } \\
\text { cấp lương thực cho các vùng có người dân định cư }\end{array}$ & Lidija 2005. \\
\hline $\begin{array}{l}\text { Rừng đô thị là các cánh rừng trong và gần khu đô thị với mục đích chính là dành cho } \\
\text { vui chơi giải trí }\end{array}$ & $\begin{array}{l}\text { Lindén, Löfström and } \\
\text { Tyrväinen for Finland }\end{array}$ \\
\hline $\begin{array}{l}\text { Rừng đô thị bao gồm các thảm thực vật có sự mặt chủ đạo của các các cây rừng nằm trong khu } \\
\text { vực đô thị bao gồm các dải rừng, rừng trồng, các loại cây có bóng, cây bụi và thảm thực vật đang } \\
\text { ở các giai đoạn diễn thế khác nhau, các vùng đất ngập nước và các vùng ven sông }\end{array}$ & $\begin{array}{l}\text { Ontario Professional } \\
\text { Foresters Act (OPFA) } \\
\text { (Canada) }\end{array}$ \\
\hline $\begin{array}{l}\text { Rừng đô thị có thể được định nghĩa là một mạng lưới hoặc hệ thống các dải rừng, một tập hợp cây } \\
\text { xanh tập trung hoặc đơn lẻ tại vùng đô thị hoặc ven đô. Chúng bao gồm: rừng, cây trên phố, cây } \\
\text { trong công việc và vườn nhà, góc phố. Rừng đô thị là xương sống cho cơ sở hạ tầng xanh cũng như } \\
\text { kết nối giữa thành thị và nông thôn, đồng thời cải thiện dấu ấn môi trường của thành phố }\end{array}$ & FAO 2017 \\
\hline
\end{tabular}




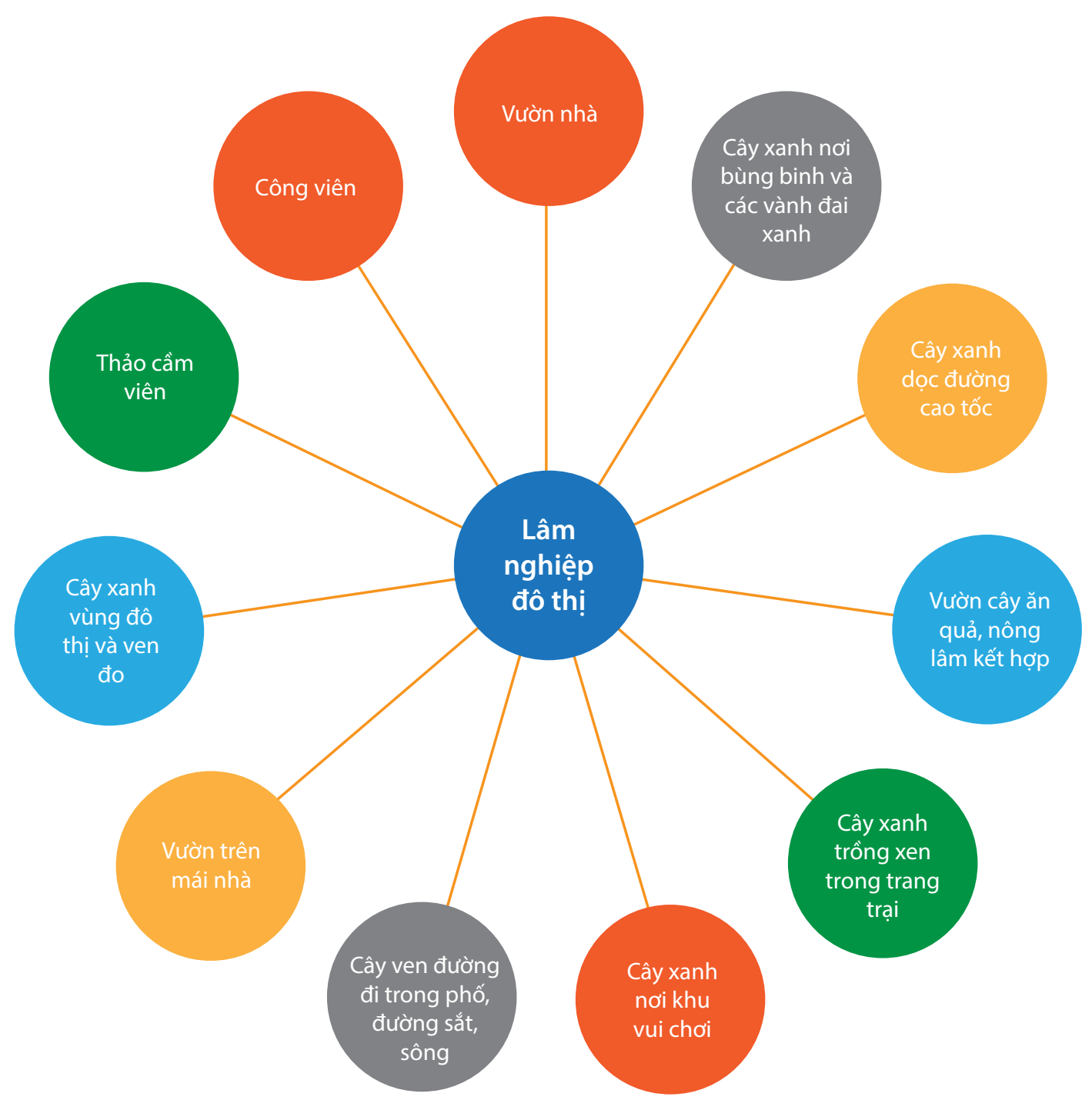

Hình 1. Phạm vi hoạt động của lâm nghiệp đô thị

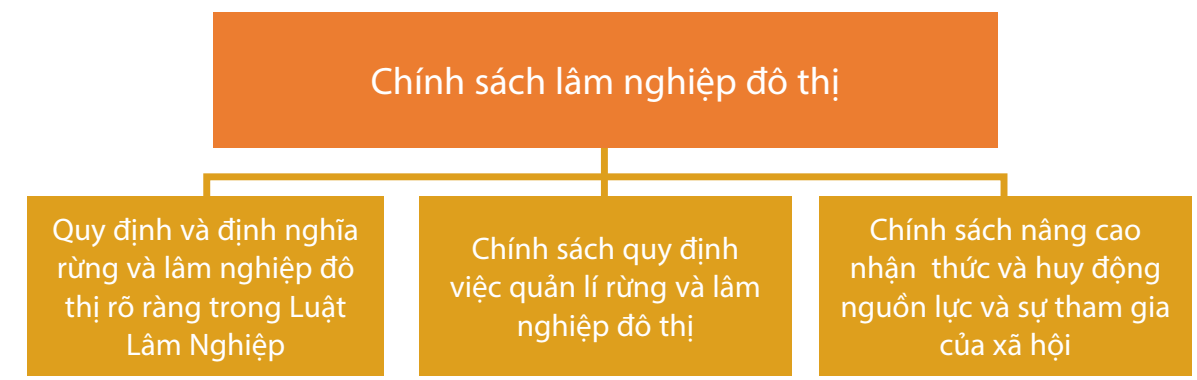

Hình 2. Các lĩnh vực chính sách liên quan tới lâm nghiệp đô thị 
Bảng 2. Nội dung và hoạt động của các chính sách liên quan đến quản lý rừng đô thị

\begin{tabular}{|c|c|}
\hline $\begin{array}{l}\text { Nội dung chính sách và quy } \\
\text { định của lâm nghiệp đô thị }\end{array}$ & Chi tiết cụ thể \\
\hline Quy hoạch & $\begin{array}{l}\text { - Sử dụng các chính sách hiện tại về phát triển hạ tầng xanh để xây dựng và lập kế hoạch } \\
\text { trồng cây } \\
\text { • Xây dựng quy hoạch và kế hoạch mở rộng công viên và diện tích cây xanh } \\
\text { • Lồng ghép lâm nghiệp đô thị vào các quy hoạch quản lý sử dụng đất và quy hoạch phát } \\
\text { triển kinh tế xã hội }\end{array}$ \\
\hline kỹ & 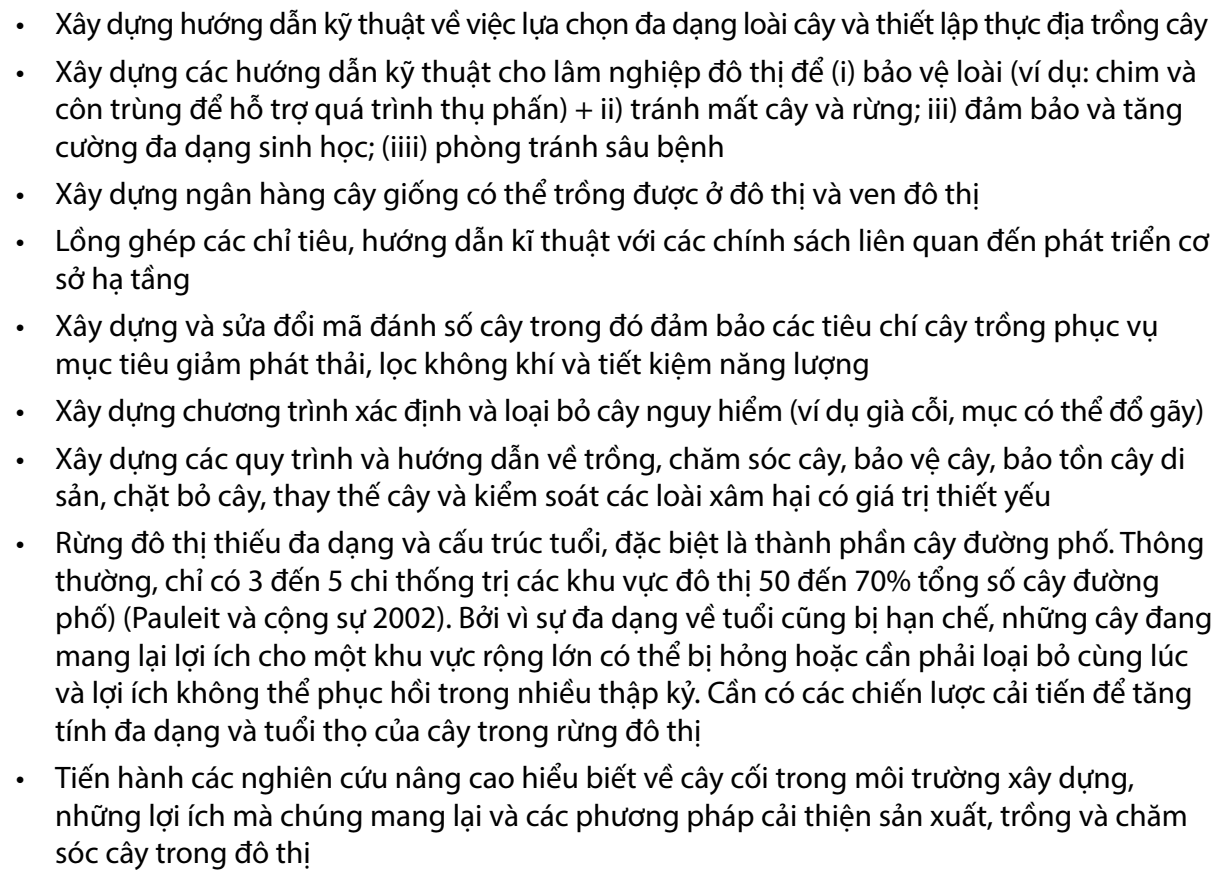 \\
\hline $\begin{array}{l}\text { Xây dựng quy trình kiểm } \\
\text { định và đội ngũ cán bộ quản } \\
\text { lý lâm nghiệp }\end{array}$ & $\begin{array}{l}\text { - Xây dựng các tổ nhóm, chuyên môn để thực hiện và quản lí các chuyên môn liên quan } \\
\text { đến lâm nghiệp đô thị } \\
\text { - Hệ thống cấp chứng chỉ và giấy phép hoạt động trong lĩnh vực lâm nghiệp đô thị } \\
\text { - Xây dựng các chương trình đào tạo trong các trường đại học, các chương trình cấp chứng } \\
\text { chỉ các kĩ năng và chuyên môn lâm nghiệp đô thị ngắn hạn, và nâng cao cung cấp các kĩ } \\
\text { năng liên quan đến lâm nghiệp đô thị } \\
\text { - Tham gia vào các hội đồng và hội đồng, mạng lưới trong và ngoài nước giúp đưa ra các } \\
\text { quyết định về lâm nghiệp đô thị }\end{array}$ \\
\hline $\begin{array}{l}\text { Xây dựng quy định, chính } \\
\text { sách giám sát và đánh giá }\end{array}$ & $\begin{array}{l}\text { - Xây dựng các chỉ số đánh giá lâm nghiệp đô thị } \\
\text { - Xây dựng các chỉ tiêu trồng cây cụ thể và có thể đo đếm được } \\
\text { - Xây dựng quy trình chuẩn "trồng đúng cây ở đúng nơi" } \\
\text { - Xây dựng các phần mềm giao diện thông minh và thân thiện để nâng cao nhận thức của } \\
\text { cộng đông về việc giám sát tài nguyên cây rừng trong thành phố } \\
\text { - Xây dựng chương trình kiểm kê rừng đô thị }\end{array}$ \\
\hline
\end{tabular}

\section{Xây dựng chính sách nâng cao nhận thức xã hội, huy động nguồn lực và sự tham gia}

Để huy động sự tham gia và nguồn lực xã hội trong lâm nghiệp đô thị, cần có nhiều chính sách hỗ trợ thúc đẩy quá trình này. Một vài gợi ý được thể hiện trong Bảng 3 dưới đây.

\section{Cơ hội đối với lâm nghiệp đô thị}

Lâm nghiệp đô thị có nhiều tiềm năng để phát triển bởi hai yếu tố sau. 
Bảng 3. Một vài chính sách và hoạt động cần thực hiện để huy động sự tham gia và nguồn lực xã hội trong việc thực hiện chính sách lâm nghiệp đô thị.

\begin{tabular}{|c|c|}
\hline $\begin{array}{l}\text { Nội dung chính } \\
\text { sách và quy định }\end{array}$ & Chi tiết cụ thể \\
\hline $\begin{array}{l}\text { Huy động cam kết } \\
\text { thực hiện chỉ số } \\
\text { xanh của các bên có } \\
\text { liên quan }\end{array}$ & $\begin{array}{l}\text { - Thiết lập các thỏa thuận giữa người dân, chính quyền và doanh nghiệp về đảm bảo chỉ số xanh } \\
\text { tối thiểu trong nơi sống và kinh doanh của họ } \\
\text { - Xây dựng các nhóm, hiệp hội ngành nghề liên quan đến lâm nghiệp đô thị } \\
\text { - Cần phải có giấy phép đối với việc chặt bỏ cây đáng kể và các ưu đãi dành cho chủ sở hữu bất } \\
\text { động sản tư nhân chủ động trông cây trên tài sản của họ }\end{array}$ \\
\hline $\begin{array}{l}\text { Huy động tài chính } \\
\text { để thực hiện lâm } \\
\text { nghiệp đô thị }\end{array}$ & $\begin{array}{l}\text { - Huy động vốn cho các dự án trồng cây xanh trong thành phố } \\
\text { - Lượng hóa tài sản của lâm nghiệp đô thị và do lâm nghiệp đô thị tạo ra tại mỗi thành phố } \\
\text { - Xây dựng các tính toán đầy đủ về vai trò lâm nghiệp đô thị trong tài khoản quốc gia } \\
\text { - Xác định và lượng hóa vai trò của lâm nghiệp đô thị trong việc giảm ô nhiễm không khí } \\
\text { - Xây dựng, cung cấp và thương mại các và chuyên gia lâm nghiệp cho các đơn vị tổ chức khác } \\
\text { ngoài ngành. Ví dư, xây dựng các dịch vụ hỗ trợ và cung cấp hướng dẫn cho các thành phố và } \\
\text { cộng đồng về kiểm kê rừng đô thị, bao gồm: thành phẩn loài, vị trí, phân bố tuổi, độ che phủ, tình } \\
\text { trạng sức khỏe, định giá dịch vụ hệ sinh thái và các mối đe dọa. Cung cấp các dịch vụ tư vấn như } \\
\text { kiểm kê cây, đánh giá rủi ro, xây dựng kế hoạch quản lý cây, cắt tỉa và chăm sóc cây, viết sắc lệnh, } \\
\text { kiểm tra và định giá cây } \\
\text { - Xây dựng chiến lược marketing cho lâm nghiệp đô thị đặc biệt với các chủ đầu tư bất động sản và } \\
\text { giới đầu tư về vai trò rừng có thể đem lại } \\
\text { - Xây dựng các chiến lược đối tác công tư }\end{array}$ \\
\hline
\end{tabular}

Nâng cao nhận thức của các bên có liên quan và huy động nguồn lực xã hội

- Làm việc với truyền thông và các phương tiện thông tin đại chúng để nâng cao nhận thức về vai trò của lâm nghiệp đô thị

- Xây dựng, công bố và đưa vào thực hiện chiến lược lâm nghiệp đô thị, rừng trong thành phố và thành phố trong rừng

- Xây dựng mạng lưới các tình nguyện viên trồng và chăm sóc cây xanh đô thị

- Kết nối với các tổ chức y tế và sức khỏe để nâng cao vai trò của lâm nghiệp đô thị

- Tổ chức và tham gia các hoạt động trồng và chăm sóc cây trong cộng đồng, trường học, không gian công cộng và đất tư nhân

- Cung cấp đào tạo nâng cao trình độ học vấn cho sinh viên, tình nguyện viên, người trồng cây, người quản lý cây và các chuyên gia khác làm việc với việc thiết lập và quản lý cây đô thị.

- Tổ chức các giải thưởng ghi nhận những công dân và tổ chức xuất sắc có ảnh hưởng tích cực trong việc tham gia hoạt động lâm nghiệp đô thị

- Xây dựng chương trình giảng dạy ở trường tiểu học, trung học và trung học cơ sở về nguyên tắc khoa học và lợi ích do lâm nghiệp đô thị mang lại

\author{
Nhu câuu sống xanh ngày càng gia tăng, đặc biệt \\ trong bối cảnh biến đổi khí hậu. Biến đổi khí hậu và ô \\ nhiễm không khí đã khiến dân cư đô thị và ven đô có \\ nhu cầu về môi trường xanh ngày càng tăng. Ở những \\ nơi có diện tích cây xanh tốt, giá trị bất động sản và \\ giá trị đầu tư cũng tăng lên nhanh chóng. Ngoài ra \\ việc có nhiều rừng trong thành phố cũng giúp tiết \\ kiệm chi phí bỏ ra để vận hành máy móc, giảm chi \\ phí khám chữa bệnh liên quan đến bệnh hô hấp và \\ bệnh tâm lý cho người dân. Nhiều nghiên cứu cũng
}

đã chỉ ra rừng đô thị cũng có thể giúp thành phố tiết kiệm chi phí bỏ ra để cải thiện hệ thống cấp thoát nước. Hiện nay Tổ chức $Y$ Tế Thế Giới khuyến cáo tỉ lệ cây xanh trong thành phố cần có để giảm thiểu các bệnh nghiêm trọng giao động từ 9-50m²/đầu người. Tuy nhiên trong thực tế, phần lớn các đô thị trên toàn cầu trong đó có Việt Nam chỉ dao động dưới $5 \mathrm{~m}^{2} /$ đầu người. Các thành phố trên thế giới đang xây dựng chiến lược mở rộng rừng và lâm nghiệp đô thị cũng sẽ tạo ra hiệu ứng lan tỏa cho các nước lân cận. 

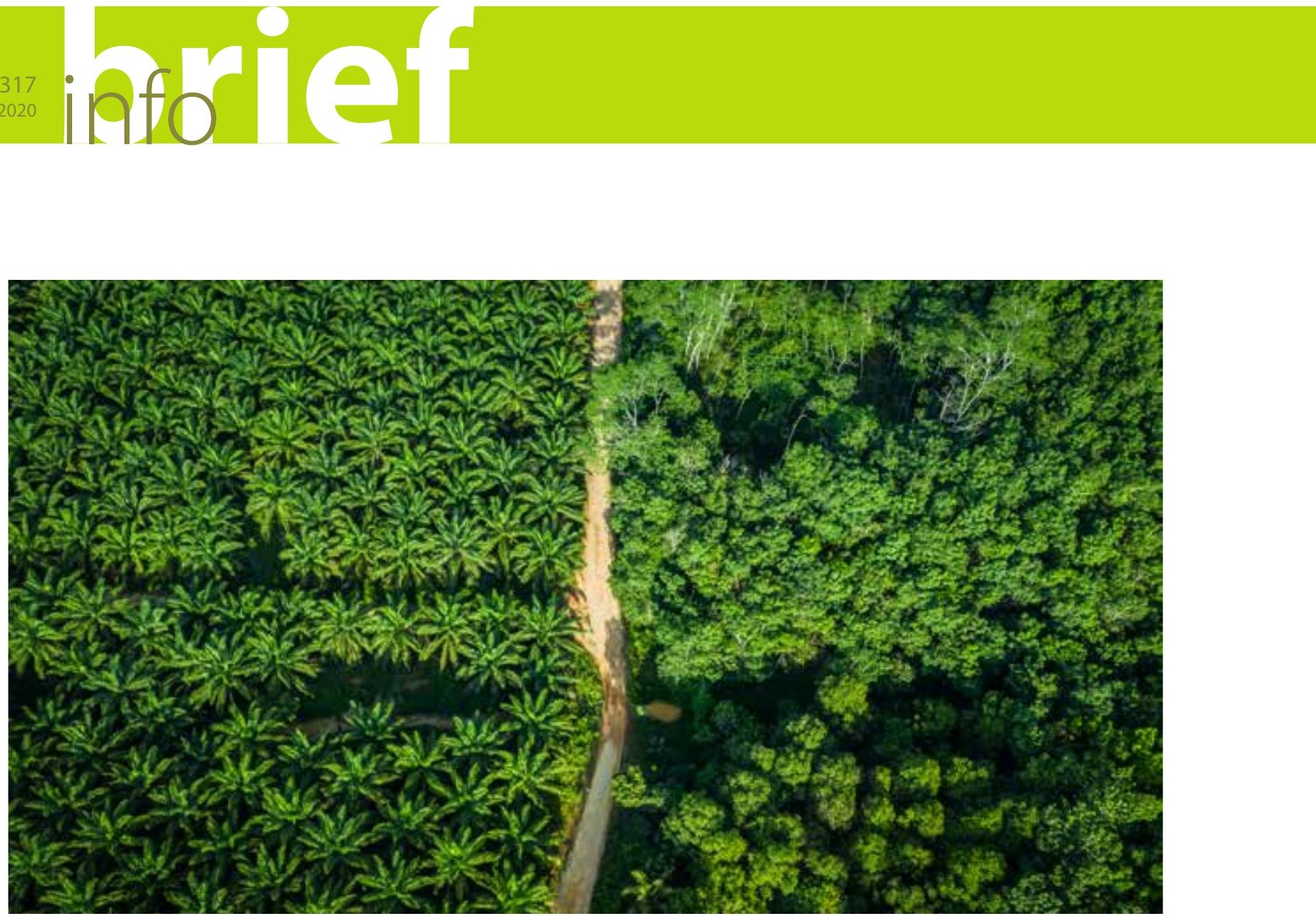

Rừng cọ trồng ở làng Muara Kaman Ilir, Kutai Kartanegara, Phía đông Kalimantan.

Ảnh chụp bởi Ricky Martin/CIFOR

\section{Các Vườn bách thảo và Thảo cầm viên là nơi cung cấp các minh chứng và bài học kinh nghiệm về việc} thực hiện đô thị. Các Vườn Bách Thảo đã có hồ sơ sưu tầm các tập hợp cây có thể sống ở đô thị cũng như có các nghiên cứu cơ bản, liên tục và dài dài hạn theo dõi nguồn gốc cây, hiện tượng bệnh, các mối đe dọa từ dịch bệnh và hiệu suất tổng thể. Các kinh nghiệm tích lũy này có thể tạo ra các bằng chứng khoa học cũng như các bài học kinh nghiệm giúp các nhà hoạch định chính sách, các nhà kiến trúc sư và cộng đồng có kiến thức về việc tổ chức trồng và quản lí các loài cây lâm nghiệp đô thị.

\section{Thách thức đối với lâm nghiệp đô thị}

Quy hoạch giữa nông nghiệp và lâm nghiệp ở các vùng đô thị và ven đô thị không rõ ràng đặc biệt là diện tích đất được sử dụng cũng như ranh giới giữa đô thị và ven đô.
Sự chồng chéo của hai khía cạnh này có thể gây khó khăn trong việc xác định các chính sách và quy định cho từng lĩnh vực.

Lâm nghiệp đô thị đòi hỏi sự phối hợp của các cấp và các ngành. Việc quản lý rừng đô thị và rừng ven đô thường liên quan tới nhiều cấp và ban ngành khác nhau. Ví dụ tại Trung Quốc, cây xanh và thảm thực vật tại đường phố và ngõ nhỏ do văn phòng địa phương chịu trách nhiệm, trong khi các tuyến đường lớn hơn thuộc sở Công viên thành phố. Trong khi đó, việc lựa chọn trồng loại cây gì lại được thực hiện bởi Văn phòng Trồng trọt thành phố với sự tham vấn của văn phòng quận và Viện Cảnh quan và Làm vườn. Việc phối hợp giữa các Sở ban ngành cũng như tại các cấp đòi phải phải có một quy trình và chính sách quy định rõ ràng phạm vi quyền hạn của từng bên, cũng như cơ chế phối hợp để tránh đẩy cao chi phí giao dịch cũng như gia tăng thủ tục hành chính. Tuy nhiên, kinh nghiệm trên thế giới cho thấy, vai trò của ngành lâm nghiệp rất quan trọng và đóng vai trò chủ chốt trong việc xây dựng các chính sách và hướng dẫn kĩ 


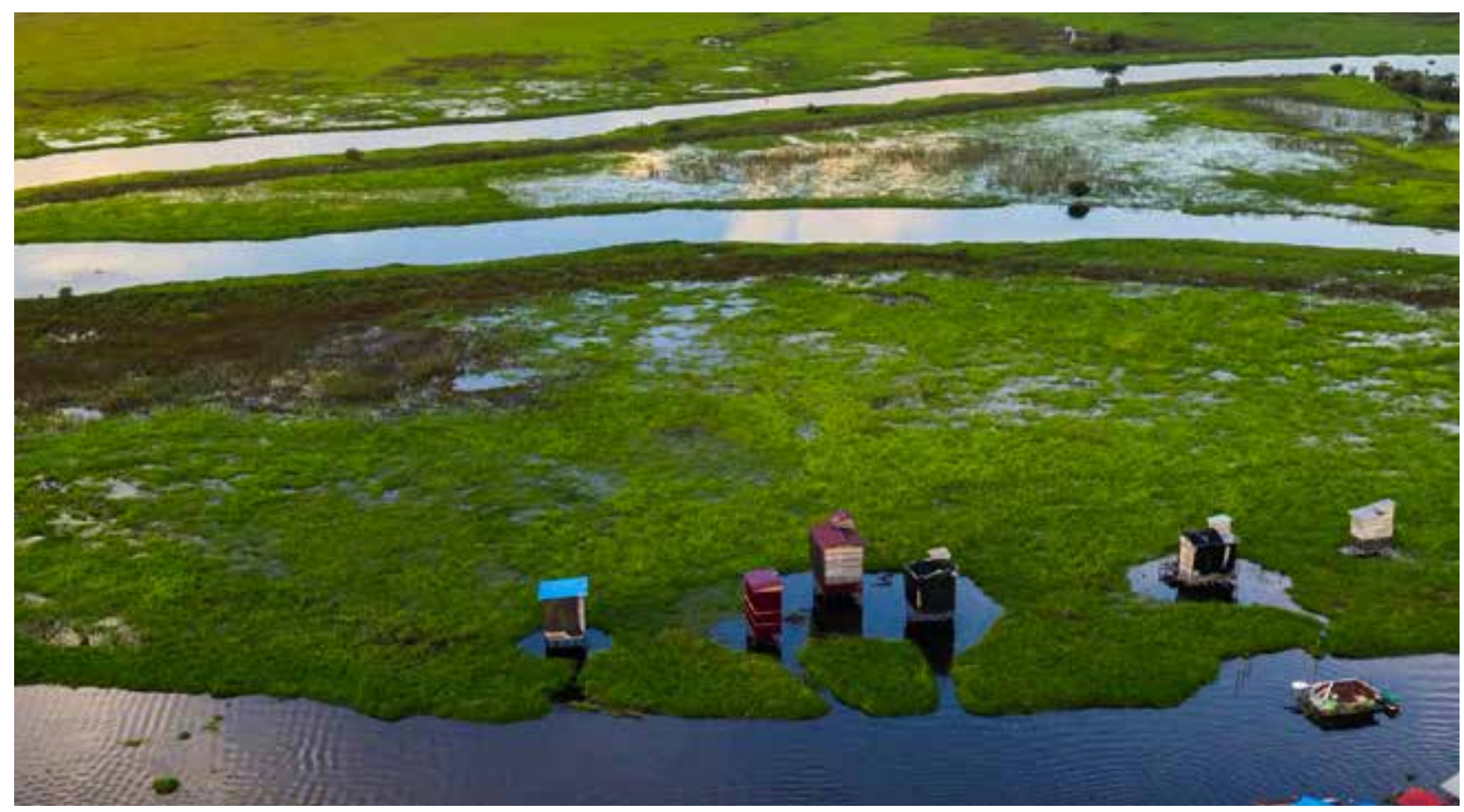

Quang cảnh của làng Sabintulung, Quận Muara Kaman, Kutai Kartanegara Regency, Phía tây Kalimantan.

Ảnh chụp bởi Ricky Martin/CIFOR

thuật chọn loài phù hợp ở nơi phù hợp cũng như đào tạo nguồn nhân lực và nâng cao nhận thức của người dân về vai trò lâm nghiệp đô thị. Mặc dù lâm nghiệp đô thị có thể do Ủy Ban Nhân Dân Thành Phố quản lý nhưng các cơ quan lâm nghiệp sẽ là người chịu trách nhiệm thẩm định và thông qua các quy định, chương trình, dự án liên quan đến lĩnh vực này.

\section{Kết luận}

Rừng và lâm nghiệp đô thị có vai trò lớn trong thích ứng và giảm thiểu biến đổi khí hậu cũng như đảm bảo lợi ích môi trường, kinh tế xã hội và an sinh của cư dân đô thị. Tuy nhiên, cần có những chính sách và hỗ trợ tài chính để đưa rừng và lâm nghiệp vào chương trình nghị sự để các nhà hoạch định chính sách và công chúng xem xét. Khi các nhà hoạch định chính sách và công chúng nhận thức rõ hơn rằng đầu tư vào lâm nghiệp đô thị có thể là một giải pháp cho nhiều vấn đề môi trường đô thị cấp bách, cây xanh sẽ được coi là ưu tiên cao hơn. Nhiều bên liên quan cần hợp tác để phát triển tầm nhìn và mục tiêu phục vụ toàn bộ cộng đồng và nhận thức rằng lâm nghiệp đô thị là một đề xuất dài hạn. Quy hoạch thành phố cần kết hợp luật bảo tồn cây xanh, quy định phát triển, tiêu chuẩn thiết kế và trồng cây cũng như các điều khoản bảo trì dài hạn. Chỉ cam kết ngắn hạn về việc trồng thêm cây xanh là chưa đủ, bởi vì sự thành công của lâm nghiệp và rừng đô thị đòi hỏi tiêu chuẩn trồng và chăm sóc tốt, lực lượng lao động được đào tạo, các chính sách hỗ trợ thực thi phối hợp liên ngành, nguồn tài chính ổn định, nhận thức đầy đủ của xã hội về vai trò của rừng và lâm nghiệp đô thị từ đó tham gia tích cực vào thực hiện chính sách này.

\section{Lời cảm ơn}

Nghiên cứu này là một phần của Nghiên cứu So sánh Toàn cầu của CIFOR về REDD + (www.cifor.org/gcs). Các đối tác tài trợ đã hỗ trợ nghiên cứu này bao gồm Cơ quan Hợp tác Phát triển Na Uy (Norad), Sáng kiến Khí hậu Quốc tế (IKI) của Bộ Môi trường, Bảo tồn Thiên nhiên, Xây dựng và An toàn Hạt nhân Liên bang Đức (BMUB) và Chương trình Nghiên cứu CGIAR về Rừng, Cây và Nông lâm kết hợp (CRP-FTA) với sự hỗ trợ tài chính từ các Nhà tài trợ Quỹ CGIAR. 


\section{Tài liệu tham khảo}

FAO. 2010. Forestry policies, institutions and programmes: South Africa.

FAO. 2017. Urban and Peri-Urban Forestry: Definition. Helms JA. 1998. The Dictionary of Forestry. Society of American Foresters.

Jess V. 2020. Urban Forests as Social-Ecological Systems. Encyclopedia of the World's Biomes: 58-70.
Lidija K. 2005. In FAO, ed. Legal and institutional aspects of urban, peri-urban forestry and greening: A working paper of discussion. FAO legal papers online 48.

Stephan P, Nerys J, Germa GM, Jose Luis GV, Louis MR, Laure VB, Monique B, Thomas BR. 2002. Tree establishment pratice in towns and cities-Results from a European survey. Urban Forestry \& Urban Greening 1(2): 83-96.
RESEARCH PROGRAM ON

Forests, Trees and Agroforestry
Chương trình nghiên cứu của CGIAR về Rừng, Cây gỗ và Nông lâm kết hợp (FTA) là chương trình phát triển nghiên cứu lớn nhất thế giới nhằm nâng cao vai trò của rừng, cây gỗ và nông lâm kết hợp với mục tiêu phát triển bền vững và đảm bảo lương thực để ứng phó với biến đổi khí hậu. CIFOR chủ trì các nghiên cứu FTA trong mối quan hệ đối tác chiến lược với Bioversity International, CATIE, CIRAD, INBAR, ICRAF và TBI.

Nghiên cứu này được hỗ trợ bởi Quỹ đối tác CGIAR: cigar.org/funders/

\section{Norad nghiên cứu sáng tạo, nâng cao năng lực của các bên đối tác, tích cực tham gia đối thoại với các bên liên quan để hỗ trợ định hình chính sách và thực tiễn tác động tới rừng và con người. CIFOR là tổ chức nghiên cứu thuộc liên minh CGIAR và chủ trì các chương trình nghiên cứu của CGIAR về Rừng, Cây gỗ và Nông lâm kết hợp (FTA). Trụ sở chính của CIFOR đặt tại Bogor, Indonesia và các văn phòng của CIFOR có mặt tại Nairobi, Kenya; Yaounde, Cameroon; Lima, Peru và Bonn, Germany. 